\title{
Lentil's (Lens culinaris L.) functional properties in prevention and treatment of non-communicable chronic diseases: A review
}

\author{
Zahra Aslani ${ }^{1}$, Beitollahe Alipour ${ }^{2}$, Parvin Mirmiran ${ }^{1}$, Zahra Bahadoran ${ }^{1}$ \\ ${ }^{1}$ Nutrition and Endocrine Research Center, and Obesity Research Center, Research Institute for Endocrine Sciences, Shahid Beheshti \\ University of Medical Sciences, Tehran, Iran \\ ${ }^{2}$ Department of Nutrition in Society, Nutrition Faculty, Tabriz University of Medical Sciences, Tabriz, Iran
}

Email address:

alipour@tbzmed.ac.ir (B. Alipour)

\section{To cite this article:}

Zahra Aslani, Beitollahe Alipour, Parvin Mirmiran, Zahra Bahadoran. Lentil's (Lens Culinaris L.) Functional Properties in Prevention and Treatment of Non-Communicable Chronic Diseases: A Review. International Journal of Nutrition and Food Sciences. Special Issue: Functional Foods and Nutraceuticals for Management of Type 2 Diabetes. Vol. 4, No. 2-1, 2015, pp. 15-20. doi: 10.11648/j.ijnfs.s.2015040201.14

\begin{abstract}
Background: using functional food in diet planning and diet therapy is one of the newest approaches in prevention and treatment of non-communicable chronic diseases. Lentil has many bioactive and functional compounds and we have reviewed the influence of lentil in prevention and treatment of chronic diseases in this review study. Materials and methods: In order to do search about mentioned objective key words including Lentils (Lens culinarisL.), functional foods, bioactive peptides, nutritional value, health polyphenol in combination with glycemic index (GI), insulin resistance, diabetes, cancer and hypertension, the sources in PubMed database were examined in the years between1986-2013. Key words such as lentils (Lens culinarisL.), functional foods, bioactive peptides, nutritional value, diabetes, cancer and hypertension were studied with access to Persian sources of Scientific Information Database (SID). Cell studies, animal models, clinical studies and review articles were used with favorable quality. Results: Lentils are rich sources of fibers, resistant starches, prebiotic compounds, phytochemicals, proteins and bioactive peptides, phenolic acids and antioxidants. Lentil has the highest total antioxidant capacity among other foods including apples, dates, raspberries, cherries, figs, oranges, garlic, cabbage and peanuts. High content of fibers and other phytochemicals are found in lentils that could improve glycemic response in diabetic patients, lipid and lipoprotein metabolism and weight management. Lentils may have favorable effects in prevention of diabetes, cancer and cardiovascular diseases $\left(\mathrm{CVD}_{\mathrm{s}}\right.$ prevalence. Conclusion: Increased dietary intake of lentils is considered as an important key in prevention and treatment of chronic diseases, especially type 2 diabetes, cardiovascular and cancer diseases.
\end{abstract}

Keywords: Lentils (Lens Culinaris L.), Functional Foods, Bioactive Peptides, Nutritional Value, Health Polyphenols

\section{Introduction}

In recent decade, science and technology have been improving and we have seen changes in life style and results of disease and death. None-communicable diseases are replaced contagious and infectious diseases [1]. Today, 47\% of the burden of chronic diseases is included in the region of Middle East [2], which are the reason of $80 \%$ of the deaths in low and middle-income countries [3]. Increasing Chronic diseases such as diabetes, cancers and coronary diseases $\left(\mathrm{CVD}_{\mathrm{s})}\right.$ increased rates of hospitalization due to them and the high cost of health care ( $60 \%$ of all admissions).So, health systems are faced with serious challenge [4]. According to side effects of drugs, use of supplementary treatments and diet modification are good ways to improve chronic diseases. Many studies have confirmed that legumes consumption effects on health promotion, control and protection against $\mathrm{CVD}_{\mathrm{s}}$ and diabetes [5, 6, 7]. Lentils are functional foods among legumes that are convenient for human consumption. High amount of protein and drought resistant put them among important plants [8, 9]. Lentils are mainly cultivated in Indian subcontinent, the Mediterranean region and North American [10]. Lentils were cultivated in 244000 hectares and its production is 166000 tons in Iran, so it has the second place after the production of chickpea [11]. Thus, the current article is a comprehensive review that addresses nutritive 
value, and functionality of lentils. In addition, impacts of lentils are investigated on high blood pressure, diabetes, $\mathrm{CVD}_{\mathrm{S}}$ and cancers.

In order to search the mentioned objective key words including Lentils (Lens culinarisL.), functional foods, bioactive peptides, nutritional value, health polyphenol in combination with glycemic index (GI), insulin resistance, diabetes, cancer and hypertension, they were examined in PubMed database in the years between1986-2013. Key words such as lentils (Lens culinarisL.), functional foods, bioactive peptides, nutritional value, diabetes, cancer and hypertension were visited with access to Persian sources of Scientific
Information Database (SID). Cell studies, animal models, clinical studies and review articles were used with favorable quality. More than 100 documents were accessible, but only 60 of them were used in this paper. As there were a few studies about objective of this paper, it is necessary to do forward studies.

\section{Nutritional Composition of Lentils}

The nutritional composition and individual nutrients of raw lentils have been identified and are mentioned in Table 1 [12].

Table 1. Nutrient content of whole lentil

\begin{tabular}{|c|c|c|c|c|}
\hline Nutrient & Unit & Value per $100 \mathrm{~g}$ & Cup 192g & Tablespoon 12g \\
\hline Water & $\mathrm{g}$ & 10.4 & 20 & 125 \\
\hline Energy & Kcal & 353 & 678 & 42 \\
\hline Protein & $\mathrm{g}$ & 25.8 & 49.5 & 3.1 \\
\hline Total fat & $\mathrm{g}$ & 1.1 & 2.4 & 0.1 \\
\hline carbohydrate & $\mathrm{g}$ & 60.1 & 115.4 & 7.2 \\
\hline Fiber & $\mathrm{g}$ & 30.5 & 58.6 & 3.7 \\
\hline sugar & $\mathrm{g}$ & 2.03 & 3.9 & 0.2 \\
\hline \multicolumn{5}{|l|}{ Minerals } \\
\hline Calciuom, $\mathrm{Ca}$ & $\mathrm{mg}$ & 55 & 108 & 7 \\
\hline Iron, $\mathrm{Fe}$ & $\mathrm{mg}$ & 7.5 & 14.5 & 0.9 \\
\hline Magnesium, $\mathrm{Mg}$ & $\mathrm{mg}$ & 122 & 234 & 15 \\
\hline Phosphorus, $\mathrm{P}$ & $\mathrm{mg}$ & 451 & 866 & 54 \\
\hline Potassium, $\mathrm{K}$ & $\mathrm{mg}$ & 955 & 1,834 & 115 \\
\hline Sodium, $\mathrm{Na}$ & $\mathrm{mg}$ & 6 & 12 & 1 \\
\hline Zinc, Zn & $\mathrm{mg}$ & 4.8 & 9.2 & 0.6 \\
\hline \multicolumn{5}{|l|}{ Vitamins } \\
\hline Vitamin C, total ascorbic acid & $\mathrm{mg}$ & 4.4 & 8.4 & 0.6 \\
\hline Thiamin & $\mathrm{mg}$ & 0.9 & 1.7 & 0.1 \\
\hline Riboflavin & $\mathrm{mg}$ & 0.2 & 0.4 & 0.03 \\
\hline Niacin & $\mathrm{mg}$ & 2.6 & 5 & 0.3 \\
\hline Vitamin B-6 & $\mathrm{mg}$ & 0.5 & 1 & 0.1 \\
\hline Folate, total DFE & $\mu \mathrm{g}$ & 479 & 920 & 57 \\
\hline Vitamin B-12 & $\mu \mathrm{g}$ & 0.00 & 0.00 & 0.00 \\
\hline Vitamin A, RAE & $\mu \mathrm{g}$ & 2 & 4 & 0 \\
\hline Vitamin A, IU & IU & 39 & 75 & 5 \\
\hline Vitamin E (a-tocopherol) & $\mathrm{mg}$ & 0.5 & 0.9 & 0.1 \\
\hline Vitamin D & IU & 0 & 0 & 0 \\
\hline Vitamin K (phylloquinone) & $\mu \mathrm{g}$ & 5 & 9.6 & 0.6 \\
\hline \multicolumn{5}{|l|}{ Lipids } \\
\hline Fatty acids, total saturated & $\mathrm{g}$ & 0.2 & 0.3 & 0.02 \\
\hline Fatty acids, total monounsaturated & $\mathrm{g}$ & 0.2 & 0.4 & 0.02 \\
\hline Fatty acids, total polyunsaturated & $\mathrm{g}$ & 0.5 & 1 & 0.1 \\
\hline Cholesterol & $\mathrm{mg}$ & 0 & 0 & 0 \\
\hline \multicolumn{5}{|l|}{ Other } \\
\hline Caffeine & $\mathrm{mg}$ & 0 & 0 & 0 \\
\hline
\end{tabular}

\subsection{Carbohydrate}

Lentils have up to $60 \mathrm{~g} / 100 \mathrm{~g}$ carbohydrates [12], such as resistant starches (RS). Many studies have confirmed that RS improve insulin sensitivity in patients with metabolic syndrome [13]. RS resist against digestive enzymes and reach the large intestine [14]. Prebiotics are indigestible carbohydrates which have some beneficial effects on host healthy by stimulating the growth and activity of one or number of bacteria in the intestinal tract and follow by health promotion [15]. In a healthy body, $80-90 \%$ of these carbohydrates are broken down to $\mathrm{CO} 2$ (carbon dioxide), hydrogen, methane and short chain fatty acids by colon bacteria's. Short chain fatty acids increase the uptake of water and sodium, colonic cell proliferation, production of metabolic energy, and the production of gastrointestinal hormones. They also stimulate blood flow to the colon and the autonomic nervous system [16]. Lentils have $13 \mathrm{gr} / 100 \mathrm{gr}$ probiotic carbohydrates [17]. Fructooligosaccarids and galactooligosaccharids are well-known for their prebiotic 
action [18]. The functional significance of these carbohydrates arises from their ability to promote the growth of beneficial gut microbes such as bifidobacterias [19].

\subsection{Fibers}

Lentils are considered as a valuable source of total dietary fibers, most of which (93-99.7\%) is insoluble and less than $7 \%$ soluble $[20,21]$. Dietary fibers have considerable effects on the physiological processes. Insoluble fibers increase water retention capacity of non-absorbed material and increase the volume and frequency of waste disposal. They also carry out gel formation in the gut tract and make complex formation with cholesterol which reduces their absorption [16]. Dietary fibers can regulate blood glucose, insulin sensitivity and reduce body weight [22]. American Diabetes Association recommends daily intakes of 20-35 grams of fibers [23]. Lectins and saponins are complex carbohydrates that are found in lentils. Lectins or haemaglutinins are carbohydrates attaching to proteins [19] and are naturally detected in lentils. These compounds have inhibitory effects on growth of cancerous cells of liver [24]; some of them could reduce carcinogenic properties by attachment to cancerous cells [25]. Several studies have demonstrated that lectins reduce rate of cell division in cancerous cells and increase machrophage numbers. Subsequently, they increase cancerous cells sensitivity to macrophage attacks, and finally improve immune system in human [26]. Lentils are among the best sources of saponins. Saponins include a diverse group of compounds characterized by their structure containing a steroid or triterpenoid aglycone [27]. There are many studies about the ability of saponins in complex formation with cholesterol [28].

\subsection{Proteins}

Lentils contain 28.7- $31.5 \%$ proteins, which is considerable among legumes [29]. Lentils are a rich source of peptides with high biological activity such as protease inhibitor proteins, angiotensin 1-converting enzyme (ACE) inhibitor and defensins [30]. Major protease inhibitor in lentils is bowman-brik type trypsine inhibitor (BBI) [31]. One of the positive effects of protein protease inhibitor is anti-inflammatory property [32]. BBI administration significantly reduced inflammation in rats with ulcerative disease [33]. Protease inhibitor proteins have an important role in treatment of cancer by mechanisms such as change in proteolytic and hydrolyze activity and altered expression of oncogenes (genes have important role in carcinogenesis) [34] ACE inhibitor destroys materials with stimulating high blood pressure [35]. Presence of peptides has been confirmed in legumes such as chickpea and lentils [36, 37].

\subsection{Fat}

Ryan and colleagues have shown that lentil seeds contained a total fat of about $1.4 \mathrm{~g} / 100 \mathrm{~g}$ distributed unevenly over the fatty fractions as follow: saturated fatty acids (SFA),
$16.7 \%$; monounsaturated fatty acids (MUFA), $23.7 \%$ and polyunsaturated fatty acids (PUFA), 58.8\% [38].

\subsection{Minerals and Vitamins}

Minerals and vitamins of lentils are presented in Table 1. Lentils have $7.5 \mathrm{mg} / 100 \mathrm{gr}$ Iron. Bioavailabity of iron can be reduced by inhibitors naturally present in the seed; this adverse effect could be minimized by cooking, germination and fermentation of lentils [39].

Zinc is an essential element for the body. Zinc is presented in more than 300 metaloenzyms, translation factors [40], metabolic pathways in protein synthesis and metabolism of carbohydrates, lipids and nucleic acids [41]. Some studies have shown the low level of zinc serum and high level of zinc exertion in diabetic people [42].

Lentils have $479 \mu \mathrm{g} / 100 \mathrm{~g}$ folate. Various evidences have suggested that folate deficiency in pregnant women has associated with spontaneous abortions and birth complications such as preterm labor. Some studies have released that folate has a protective effect against cancers such as breast cancer, colorectal, pancreas and esophagus [43].

\subsection{Phytochemicals}

Lentils have high amount of phytochemical compounds like Polyphenols. Polyphenols are secondary metabolites that have major role in tissue protection against free radicals; therefore lentils may drop the rates of cancer, diabetes, Parkinson, heart failure and alzheimer [37]. Among polyphenols, tannins and tannin-related compounds are principal components in lentils, which mainly concentrated in the testa. Lentils are being among the richest legume seeds in their condensed tannin content, up to $915 \mathrm{mg} / 100 \mathrm{~g}$ (1).On the other hand, flavonoids and 3-O-glucoside distribute in the seed coat. The coat also contains glycosides of flavonols and proanthocyanidins $[37,45]$. It has been found that the darkness of the coat of colored pules such as lentils are correlated with their phenolic compounds [46]. Green or red lentils have a significantly higher phenolic content and antioxidant capacity than that of the pale colored pules [47]. Seed coat represents only a small percentage of the entire lentil seed weight, ranging from 8 to $11 \%$, but provides significant contribution to the benefits of lentils [48]. The concentration of simple polyphenols determined in the cooked lentils 2404lg/100 [49]. Lentils have the highest antioxidant capacity among pules [50]. Lentils had higher oxygen radical absorbing capacity (ORAC) value than most of the common fruits and vegetables including apples, plums, blackberries, cherries, figs, peaches, pears, oranges, garlic, cabbage and almonds [51].

\section{Favorable Effects of Lentils}

\subsection{Body Weight Regulation}

The high fiber content and low glycemic response of lentils have been looked as a means of increasing satiety, 
reducing food intake and thus controlling body weight [52]. Some observational studies have consistently showed an inverse relationship between pulses consumption and body mass index (BMI) or risk for obesity [53].

\subsection{Cardiovascular Diseases}

In a meta-analysis of eleven clinical trials that examined the effects of pulses on serum lipoproteins, results reported that intake of non-soya pulses, including lentils, was related with reduction in serum total cholesterol (TC), low density lipoprotein cholesterol (LDL-C), triglycerides (TG) and an improvement in high density lipoproteins cholesterol (HDL-
C). The reviewers described that the hypocholesterolemic effects of pulses are related with presence of soluble dietary fiber, vegetable proteins, oligosaccharides, isoflavones, fatty acids, saponins and other factors [37].

\subsection{Diabetes}

Lentils have low glycemic index (GI), which slowly release glucose into the bloodstream and create a constant insulin response. According to these results, lentils are recommended for patients with type 2 diabetes and $\mathrm{CVD}_{\mathrm{s}}$ [54]. Some studies have demonstrated effects of lentils on rats [55] and humans with type 2 diabetes [56] (Table 2).

Table 2. Studies were conducted about effect of lentil.

\begin{tabular}{|c|c|c|c|}
\hline Researcher (year) & Study design & Intervention / treatment & Findings \\
\hline $\begin{array}{l}\text { Tibi et al } \\
\text { performed in } 2010 \\
{[55]}\end{array}$ & Animal models/40 male rats & $\begin{array}{l}\text { Rats were nourished by whole cooked } \\
\text { lentil, whole raw lentil, without raw testa } \\
\text { lentil, without cooked testa lentil for } 6 \text { - } \\
\text { weeks. }\end{array}$ & $\begin{array}{l}\text { HDL-C was significantly higher in rats } \\
\text { which consumed whole cooked lentil. } \\
\text { Serum glucose was significantly lower in } \\
\text { rats which consumed without cooked } \\
\text { testa lentil. }\end{array}$ \\
\hline $\begin{array}{l}\text { Shams et al excuted } \\
\text { it in } 2010 \text { [56]. }\end{array}$ & $\begin{array}{l}\text { Clinical trial } / 30 \text { patients with type } 2 \\
\text { diabetes }\end{array}$ & $\begin{array}{l}\text { Participants received } 50 \mathrm{gr} / \mathrm{d} \text { cooked } \\
\text { lentils for } 6 \text { weeks }\end{array}$ & $\begin{array}{l}\text { Serum glucose and total cholesterol } \\
\text { significantly decreased. }\end{array}$ \\
\hline $\begin{array}{l}\text { Adebamowo } \\
\text { et al excuted this } \\
\text { study in } 2005 \text { [60]. }\end{array}$ & $\begin{array}{l}\text { In a prospective study } 90,630 \text { women } \\
\text { who were premenstrual and aged } 26-46 \text {. } \\
\text { They were followed up during } 8 \text { years. }\end{array}$ & $\begin{array}{l}\text { Flavanol intake of participants was } \\
\text { examined by food frequency } \\
\text { questionnaires. }\end{array}$ & $\begin{array}{l}\text { There was significant inverse association } \\
\text { with intake of beans or lentils with breast } \\
\text { cancer risk. }\end{array}$ \\
\hline
\end{tabular}

Cancer: lentils have some bioactive components with anticarcinogenic properties including lectins and defensins which can improve statue of patients with colorectal cancer [57]. The incidence of breast, prostate and colon cancer is low in populations that have higher amount of lentils in their diet [58]. Preventive and treatment effects of lentils are showed in patients with cancers (Table 2) [59, 60]. Anti-carcinogenic mechanisms of lentils are including hormones modulation and improvement in the level of antioxidants such as glutathione peroxidase, increase in the level of E-2 prostaglendin, reduction in amplification of the protoancogens and apoptotic programmed cell dead $[59,60]$.

\section{Conclusion}

Due to the components such as high fibers, prebiotics, unsaturated fatty acids, bioactive peptides, vitamins, minerals and polyphenol compounds, lentils are important functional foods. Lentils have a major role in health improvement and protection against non- communicable diseases. Further investigations as human clinical studies are needed to obtain the optimum dose and duration of lentil consumption in diabetic patients.

\section{References}

[1] Pruitt S, Annandale S. Innovative care for chronic conditions: building blocks for action: global report: Noncommunicable Diseases and Mental Health, WHO. 2002:11-29.
[2] Khatib O. Noncommunicable diseases: risk factors and regional strategies for prevention and care. East Mediterr Health J. 2004;10(6):778-88.

[3] Tunstall-Pedoe H. Preventing Chronic Diseases. A Vital Investment: WHO Global Report. Geneva: World Health Organization, 2005. pp 200. CHF 30.00. ISBN 9241563001. Also published on http://www. who. int/chp/chronic_disease_report/en. Int. J. Epidemiol. 2006;35(4):1107-.

[4] Nolte E, McKee M. Caring For People With Chronic Conditions: A Health System Perspective: A Health System Perspective: McGraw-Hill International; 2008.

[5] Englyst KN, Vinoy S, Englyst HN, Lang V. Glycaemic index of cereal products explained by their content of rapidly and slowly available glucose. BJN. 2003;89(03):329-39.

[6] Foster-Powell K, Holt SH, Brand-Miller JC. International table of glycemic index and glycemic load values: 2002. Am. J. Clin. Nutr.. 2002;76(1):5-56.

[7] Lukito W. Candidate foods in the Asia-Pacific region for cardiovascular protection: nuts, soy, lentils and tempe. APJCN. 2001;10(2):128-33.

[8] Francis CA. Sustainable agriculture: myths and realities. J SUSTAIN AGR. 1990;1(1):97-106.

[9] Solanki I, Kapoor A, Singh U. Nutritional parameters and yield evaluation of newly developed genotypes of lentil (Lens culinaris Medik.). Plant Foods Hum Nutr. 1999;54(1):79-87.

[10] Muehlbauer F, Kaiser W, Clement S, Summerfield R. Production and breeding of lentil. Adv Agron. 1995. 
[11] Nakgforoush A, Kouchaki A, Bagheri M. Morphological and physiological parameters of affecting the yield of different genotypes of lentils. IJACS. 1996.

[12] National Nutrient Database for Standard Reference Release 25 2013 Available from: http://ndb.nal.usda.gov/ndb/foods/show/4683.

[13] Johnston K, Thomas E, Bell J, Frost G, Robertson M. Resistant starch improves insulin sensitivity in metabolic syndrome. Diabetic Med. 2010;27(4):391-7.

[14] Perera A, Meda V, Tyler R. Resistant starch: A review of analytical protocols for determining resistant starch and of factors affecting the resistant starch content of foods. FOOD REV INT. 2010;43(8):1959-74.

[15] Mahious A, Gatesoupe F, Hervi M, Metailler R, Ollevier F. Effect of dietary inulin and oligosaccharides as prebiotics for weaning turbot, Psetta maxima (Linnaeus, C. 1758). Aquac In. 2006;14(3):219-29.

[16] Mahan LK, Escott-Stump S, Raymond JL, Krause MV. Krause's food \& nutrition therapy. 2012.

[17] Huynh B-L, Palmer L, Mather DE, Wallwork H, Graham RD, Welch RM, et al. Genotypic variation in wheat grain fructan content revealed by a simplified HPLC method. J Cereal Sci.. 2008;48(2):369-78.

[18] Bhatty R. Composition and Quality of Lentil ( Lens culinaris Medik): A Review. Can Inst Food Sci Technol J. 1988;21(2):144-60

[19] Scholtens PA, Alles MS, Bindels JG, van der Linde EG, Tolboom JJ, Knol J. Bifidogenic effects of solid weaning foods with added prebiotic oligosaccharides: a randomised controlled clinical trial. J. Pediatr. Gastroenterol. Nutr.. 2006;42(5):553-9.

[20] de Almeida Costa GE, da Silva Queiroz-Monici K, Pissini Machado Reis SM, de Oliveira AC. Chemical composition, dietary fibre and resistant starch contents of raw and cooked pea, common bean, chickpea and lentil legumes. Food Chem. 2006;94(3):327-30.

[21] Bednar GE, Patil AR, Murray SM, Grieshop CM, Merchen NR, Fahey GC. Starch and fiber fractions in selected food and feed ingredients affect their small intestinal digestibility and fermentability and their large bowel fermentability in vitro in a canine model. J. Nutr. 2001;131(2):276-86.

[22] Shidfar F, Keshavarz A, Avaspour M. The effect of two types of bread with different fiber contents on biochemical parameters of patients with type II diabetes. IJEM. 2001;3(4):257-64.

[23] Chandalia M, Garg A, Lutjohann D, von Bergmann K, Grundy SM, Brinkley LJ. Beneficial effects of high dietary fiber intake in patients with type 2 diabetes mellitus. NEJM.2000;342(19):1392-8.

[24] Roy F, Boye J, Simpson B. Bioactive proteins and peptides in pulse crops: Pea, chickpea and lentil. FRI. 2010;43(2):432-42.

[25] Bures L, Bostik J, Motycka K, Spundova M, Rehak L. The use of protein as a carrier of methotrexate for experimental cancer chemotherapy. III. Human serum albuminmethotrexate derivative, its preparation and basic testing. Neoplasma. 1987;35(3):329-42.
[26] Barać MB, Stanojević SP, Pešić MB. Biologically active components of soybeans and soy protein products: A review. APT. 2005 (36):155-68.

[27] Güçlü-Üstündağ Ö, Mazza G. Saponins: properties, applications and processing. Crit. Rev. Food Sci. Nutr. 2007;47(3):231-58.

[28] Hostettman K, Marston A, Hostettman K. Saponins: Chemistry and Pharmacology of Natural Products. ACS Publications; 1996.

[29] Maninder K, Sandhu KS, Singh N. Comparative study of the functional, thermal and pasting properties of flours from different field pea (Pisum sativum L.) and pigeon pea (Cajanus cajan L.) cultivars. Food chem. 2007;104(1):259-67.

[30] El-Adawy T, Rahma E, El-Bedawey A, El-Beltagy A. Nutritional potential and functional properties of germinated mung bean, pea and lentil seeds. PLANT FOOD HUM NUTR. 2003;58(3):1-13.

[31] Cheung AH, Ng TB. Isolation and characterization of a trypsin-chymotrypsin inhibitor from the seeds of green lentil (Lens culinaris). Protein Pept. Lett. 2007;14(9):859-64.

[32] Kennedy A. Cancer prevention by protease inhibitors. Prev. Med. 1993;22(5):796-811.

[33] Ware JH, Wan XS, Newberne P, Kennedy AR. Bowman-Birk inhibitor concentrate reduces colon inflammation in mice with dextran sulfate sodium-induced ulcerative colitis. Dig. Dis. Sci. 1999;44(5):986-90.

[34] Morse MA, Stoner GD. Cancer chemoprevention: principles and prospects. Carcinogenesis. 1993;14(9):1737-46.

[35] Dzau V. Circulating versus local renin-angiotensin system in cardiovascular homeostasis. Circulation. 1988;77(6 Pt 2):I4-13.

[36] Kuba M, Tana C, Tawata S, Yasuda M. Production of angiotensin I-converting enzyme inhibitory peptides from soybean protein with Monascus purpureus acid proteinase. Process biochem. 2005;40(6):2191-6.

[37] Anderson JW, Major AW. Pulses and lipaemia, short-and longterm effect: potential in the prevention of cardiovascular disease. BJN. 2002;88(S3):263-71.

[38] Ryan E, Galvin K, O'Connor T, Maguire A, O'Brien N. Phytosterol, squalene, tocopherol content and fatty acid profile of selected seeds, grains, and legumes. PLANT FOOD HUM NUTR. 2007;62(3):85-91.

[39] Umeta M, West C, Fufa H. Content of $\mathrm{Zn}, \mathrm{Fe}, \mathrm{Ca}$ and their absorption inhibitors in foods commonly consumed in Ethiopia. J Food Comp Anal 2005;18(803-817).

[40] Adachi Y, Yoshida J, Kodera Y, Kiss T, Jakusch T, Enyedy EA, et al. Oral administration of a zinc complex improves type 2 diabetes and metabolic syndromes. Biochem. Biophys. Res. Commun.. 2006;351(1):165-70.

[41] Marreiro DN, Geloneze B, Tambascia MA, Lerário AC, Halpern A, Cozzolino SM. Participation of zinc in insulin resistance. Arq Bras Endocrinol Metabol. 2004;48(2):234-9.

[42] Chausmer AB. Zinc, insulin and diabetes. J Am Coll Nutr. 1998;17(2):109-15. 
[43] Fayet F, Flood V, Petocz P, Samman S. Relative and biomarker-based validity of a food frequency questionnaire that measures the intakes of vitamin B sub 12sub, folate, iron, and zinc in young women. NUTR RES. 2011;31(1):14-20.

[44] Salariya AM. The effects of hydrothermal processing on antinutrients, protein and starch digestibility of food legumes. International journal of food science \& technology. 2005;40(7):695-700.

[45] Dueñas M, Sun B, Hernández T, Estrella I, Spranger MI. Proanthocyanidin composition in the seed coat of lentils (Lens culinaris L.). J AGR FOOD CHEM. 2003;51(27):7999-8004.

[46] Xu B, Yuan S, Chang S. Comparative analyses of phenolic composition, antioxidant capacity, and color of cool season legumes and other selected food legumes. J. Food Sci.. 2007;72(2):S167-S77.

[47] Xu B, Chang SK. Phenolic substance characterization and chemical and cell-based antioxidant activities of 11 lentils grown in the Northern United States. J AGR FOOD CHEM. 2010;58(3):1509-17.

[48] Dueñas M, Hernández T, Estrella I. Assessment of in vitro antioxidant capacity of the seed coat and the cotyledon of legumes in relation to their phenolic contents. Food Chem. 2006;98(1):95-103.

[49] Kalogeropoulos N, Chiou A, Ioannou M, Karathanos V, Hassapidou M, Nikolaos K, et al. Nutritional evaluation and bioactive microconstituents (phytosterols, to-copherols, polyphenols, triterpenic acids) in cooked dry le-gumes usually consumed in the Mediterranean countries. Food Chem. 2010;121:682-90.

[50] Bouchenak M, Lamri-Senhadji M. Nutritional quality of legumes, and their role in cardiometabolic risk prevention: a review. J Med Food. 2013;16(3):185-98.

[51] Low PA, Nickander KK, Tritschler HJ. The roles of oxidative stress and antioxidant treatment in experimental diabetic neuropathy. Diabetes. 1997;46(Supplement 2):S38-S42.
[52] Mollard R, Zykus A, Luhovyy B, Nunez M, Wong C, Anderson G. The acute effects of a pulse-containing meal on glycaemic responses and measures of satiety and satiation within and at a later meal. B JN. 2012;108(03):509-17.

[53] McCrory MA, Hamaker BR, Lovejoy JC, Eichelsdoerfer PE. Pulse consumption, satiety, and weight management. Adv Nutr. 2010;1(1):17-30.

[54] Chung H-J, Liu Q, Hoover R, Warkentin TD, Vandenberg B. In vitro starch digestibility, expected glycemic index, and thermal and pasting properties of flours from pea, lentil and chickpea cultivars. Food chem. 2008;111(2):316-21.

[55] Al-Tibi AM, Takruri HR, Ahmad MN. Effect of dehulling and cooking of lentils (Lens culinaris L.) on serum glucose and lipoprotein levels in streptozotocin-induced diabetic rats. Malays J Nutr. 2010;16:83-92.

[56] Shams H, Tahbaz F, Abadi A. Effects of cooked lentils on glycemic control and blood lipids of patients with type 2 diabetes. ARYA Atheroscler. 2010;4(1).

[57] De Mejía EG, Prisecaru VI. Lectins as bioactive plant proteins: a potential in cancer treatment. Crit. Rev. Food Sci. Nutr.. 2005;45(6):425-45.

[58] 58.Correa P. Epidemiological correlations between diet and cancer frequency. Cancer res. 1981;41(9 Part 2):3685-9.

[59] Faris MeA-IE, Takruri HR, Shomaf MS, Bustanji YK. Chemopreventive effect of raw and cooked lentils (Lens culinari L) and soybeans (Glycine max) against azoxymethane-induced aberrant crypt foci. Nutr res. 2009;29(5):355-62.

[60] Adebamowo CA, Cho E, Sampson L, Katan MB, Spiegelman D, Willett WC, et al. Dietary flavonols and flavonol - rich foods intake and the risk of breast cancer. International Journal of Cancer.2005;114(4):628-33. 